\title{
Postharvest Longevity of Cut Gerbera and Alstroemeria as Affected by Citric Acid Pulse and Vase Solutions
}

\author{
H.H.D.I. Lakmali*, B.L.S. Balasooriya and K. Ratnayake
}

\begin{abstract}
End-user vase life of two popular cut flowers, gerbera (Gerbera jamesonii) and alstroemeria (Alstroemeria spp.) is limited due to non-adoption of appropriate postharvest treatments in Sri Lanka. Citric acid-based cut flower preservatives could be affordable treatments to extend the longevity of those species. Therefore, a study was carried out to investigate the effectiveness of pulse and vase solution treatments with citric acid for increasing the keeping quality of cut gerbera and alstroemeria flowers. For pulsing, cut flower stems were treated with 0 $\mathrm{mM}$ (distilled water), 5, 10 and $15 \mathrm{mM}$ citric acid combined with 5, 16 and 24 h pulsing durations. Only alstroemeria was further tested with $0,15,25$ and $30 \mathrm{mM}$ citric acid with previous pulsing durations. Pulsed stems were stood into distilled water for vase life evaluation. For vase solution treatment, citric acid at $0,1,2,5$ and $10 \mathrm{mM}$ concentrations were incorporated in vase water. In the next step, two levels of citric acid $(0,1 \mathrm{mM})$ were combined with four levels of sucrose $(0,1,2,5 \%)$ in vase water for gerbera. Factorial experiments were arranged in completely randomized design with five to ten replicates. Data on vase life, relative fresh weight and solution uptake rate were recorded. Pulse treatments were ineffective for improving vase life. Nevertheless, a vase solution with $1 \mathrm{mM}$ citric acid showed a 2 -fold increase in vase life and a better retention of fresh weight in cut gerbera. Incorporation of citric acid in
\end{abstract}

Department of Horticulture \& Landscape Gardening, Faculty of Agriculture and Plantation Management, Wayamba University of Sri Lanka, Gonawila 60170, Sri Lanka

*hhdireshalakmali@gmail.com vase water did not extend the vase life of cut alstroemeria flowers. Combining citric acid with sugar in the vase solution maintained favourable relative fresh weight, water uptake rates and vase life in cut gerbera. Thus, incorporation of $1 \mathrm{mM}$ citric acid and $1-2 \%$ sugar in vase or holding solutions could improve the longevity of cut gerbera flowers.

Keywords: Alstroemeria, Citric acid, Gerbera, Sucrose, Vase life

\section{INTRODUCTION}

Floriculture in Sri Lanka started as an industry in 1970s. Western, North Western and Central provinces in Sri Lanka are the major areas where cut flowers are grown commercially (Dhanasekera, 1998). Today, floriculture is recognized as a profitable industry in Sri Lanka since it generates a higher income per unit area when compared to many other crops. Currently, Sri Lanka exports cut flowers to Japan, The Netherlands, Canada and The United Kingdom (Kelegama, 2001). Increasing trend in exports indicates the rising demand for Sri Lankan products in many markets around the world. The sector generates high net foreign exchange earnings to the country while contributing to employment generation in the rural and suburban areas. The Export Development Board of Sri Lanka (EDB) has, in its five-year plan, identified floriculture as a key contributor which needs promotion and development in 
Sri Lanka (Senarathne, 2014).

Alstroemeria (Alstroemeria spp.) and gerbera (Gerbera jamesonii) are two major cut flower species having a high demand in the domestic market of Sri Lanka (Idirisinghe et al., 2013). However, stem bending and short vase life is one of the major postharvest problems in cut gerbera during retail selling (Khenizy et al., 2013). Alstroemeria (Alstroemeria spp.) is popularly used in bouquets and flower arrangements. Maintaining leaf quality is one of the major postharvest problems with this crop as the leaves will turn yellow before the flowers have declined (Yeat et al., 2004). The volumes discarded in alstroemeria are relatively higher at retail shops in Sri Lanka because of leaf yellowing and flower drop (Idirisinghe et al., 2013).

Water balance is a major factor determining the quality and longevity of cut flowers. It is influenced by water uptake, transpiration and the balance between the two mentioned processes. Many agents have been used in cut flower vase solutions to extend the vase life by improving water uptake (Mohammadiju et al., 2014). However, in many cut flower retail sites in Sri Lanka, just water, without any chemical preservative or flower food source, is used as the holding solution. A majority $(81 \%)$ of retailers maintain those cut flowers at room temperature while only a few of them use cool rooms or cold chain during marketing. These conditions could increase the rate of water loss and accelerate senescence in cut gerbera and alstroemeria flowers (Idirisinghe et al., 2013; Chandrasena et al., 2015).

Water with a low $\mathrm{pH}$ is taken up by the cut flowers faster and more easily (Gast, 1997). Citric acid or a weak organic acid is usually used to acidify the water. Citric acid increased the turgidity and the number of opened florets in cut tuberose flowers compared to other treatments (Alvarez et al., 1994). Citric acid has been added to vase solutions to improve the vase life in cut roses (Jowkar et al., 2012), Acacia amoena (Williamson and Milburn, 1996) and Eucalyptus spp. (Delaporte et al., 2000). Although the mechanism of citric acid is unknown, it is believed to decrease the microbial growth, increase hydraulic conductance and improve tissue water potentials (Williamson and Milburn, 1996).

Presence of sugar in the vase solution has effectively delayed petal wilting and abscission, and prolonged the freshness of many cut flowers. Sucrose is the most common carbohydrate source used in floral preservatives. It acts as a respiratory substrate and delays the degradation of proteins and improves the water balance of cut flowers (Khenizy et al., 2013).

This study was carried out to investigate the effect of citric acid as a pulse and vase solution along with sucrose treatment on the vase life of cut gerbera and alstroemeria flowers, with a view to introduce an effective low cost and environmental friendly holding and vase solutions for the floriculture industry. 


\section{MATERIALS AND METHODS Experimental Material and Set-Up}

The experiments were conducted at the Horticulture Laboratory, Wayamba University of Sri Lanka, Makandura, from March to July 2014. Gerbera (Gerbera jamesonii var. Candela) and alstroemeria (Alstroemeria var. Tiesto) flowers grown in Nuwara Eliya were obtained from a retail centre in Negombo (North Western Province), Sri Lanka. Those flowers were selected based on uniformity and quality avoiding malformations or damages.

The stems were immersed in water and transported to laboratory within $30 \mathrm{~min}$. Before treatment, the stems were re-cut under water to $30 \mathrm{~cm}$ length. Those cut flowers were placed into clean bottles filled with $250 \mathrm{ml}$ of treatment solutions. Mouths of the bottles were covered with Parafilm ${ }^{\circledR}$ to avoid evaporation of the solutions. Solutions of citric acid (AR Grade, Techno Pharmchem, India) were freshly prepared in distilled water.

Temperature and relative humidity (RH) in the vase life evaluation environment were recorded using a data logger (DTM-322, TECPEL Co. Ltd., Taiwan). Those were $30 \pm 1{ }^{\circ} \mathrm{C}$ and $79 \pm 8 \%$ (mean $\pm \mathrm{SD}$ ), respectively. A $12 \mathrm{~h}$ photoperiod was provided using fluorescent lights. Vase solution $\mathrm{pH}$ was measured in freshly prepared solutions and thereafter at 3 days intervals using a $\mathrm{pH}$ meter (Starter 3000, Ohaus Corporation, USA).

\section{Citric Acid Pulse Treatment}

For pulsing, the experiment was conducted in two parts. In Experiment 1, cut alstroemeria and gerbera were pulsed with four citric acid concentrations of $0 \mathrm{mM}$ (Distilled water; Control), 5, 10 and, 15 $\mathrm{mM}$; Williamson et al., 2002) for three durations of 5, 16 and 24 h. In Experiment 2 , alstroemeria was tested with four citric acid concentrations of $0,15,25$ and $30 \mathrm{mM}$ for the above mentioned pulsing durations (Table 1). After pulsing, stems were individually transferred to vases with 200 $\mathrm{ml}$ of distilled water for vase life evaluation.

\section{Citric Acid Vase Solution Treatment}

In Experiment 3, Citric acid was used as a vase solution additive in concentrations of 0 mM (distilled water; Control; $\mathrm{pH}$ 6.5), 1 $\mathrm{mM}$ ( $\mathrm{pH} 2.79), 2 \mathrm{mM}$ ( $\mathrm{pH} 2.8), 5 \mathrm{mM}$ ( $\mathrm{pH}$ $2.4)$, and $10 \mathrm{mM}(\mathrm{pH} \mathrm{2.2)}$ in vase water (Jowkar et al., 2012). Then, the best citric acid treatment for cut gerbera was selected and it was combined with $0 \%$ (distilled water), 1, 2, and 5\% of sugar (sucrose) concentrations (Delaporte et al., 2000) in Experiment 4 (Table 2).

\section{Determination of Vase Life}

Cut flowers were assessed daily for their visual appeal. Overall appearance and the quality of flowers were recorded using a scale developed for the evaluation of flower quality. The vase life of gerbera ended at $\geq 90^{\circ}$ stem bending, $\geq 50 \%$ petal discoloration and $l o r \geq 50 \%$ outward curling of petals. In alstroemeria, $\geq 50 \%$ leaf 
yellowing andlor petal abscission of $>25 \%$ was considered to terminate the vase life.

\section{Relative Fresh Weight Measurements (RFW)}

The vases with and without flowers were weighed daily using an electronic top loading balance. For weighing, flowers were taken out from water for as short a time as possible (20-30 s). Relative Fresh Weight (RFW) of stems were calculated using the formula: RFW $(\%)=\left(\mathrm{W}_{\mathrm{t}} / \mathrm{W}_{\mathrm{t}=0}\right)$ $\mathrm{x} 100$; where, $\mathrm{W}_{\mathrm{t}}$ is the current day's weight of stem $(\mathrm{g})$ at $\mathrm{t}=$ day $0,1,2$, etc., and $\mathrm{W}_{\mathrm{t}}=\mathbf{0}$ is the weight of same stem $(\mathrm{g})$ at $\mathrm{t}=$ day 0 (He et al., 2006).

\section{Vase Solution Uptake Rate (SUR)}

Average daily vase solution uptake was calculated by the formula: Vase Solution Uptake Rate $\left(\mathrm{g} / \mathrm{g}\right.$ Initial FW) $=\left(\mathrm{S}_{\mathrm{t}-1}-\mathrm{S}_{\mathrm{t}}\right) /$ FW; where $S_{t}$ is the current day's weight of vase solution $(\mathrm{g})$ at $\mathrm{t}=1,2,3$, etc., $\mathrm{S}_{\mathrm{t}-1}$ is the weight of vase solution $(\mathrm{g})$ on the previous day. FW is initial stem fresh weight at day 0 (He et al., 2006).

\section{Experimental Design and Statistical Analysis}

For pulse treatment (Experiments 1 and 2), 10 treatments were factorially arranged in a completely randomized design with five replicates for each combination. In vase solution treatments, Experiment 3 with five treatments was arranged in a completely randomized design (CRD) with 10 replicates. Experiment 4 was designed as a
CRD factorial experiment with eight treatment combinations each having five replicates.

Data on vase life, RFW and SUR were recorded daily. Data analysis was done by the General Linear Model (GLM) or Analysis of Variance (ANOVA) procedures using Statistical Analysis System (SAS) Version 9.2 (SAS institute Inc., Cary, NC, USA). Differences among means were determined by Least Significant Difference (L.S.D) test at 5\% level of probability.

\section{RESULTS AND DISCUSSION Efficacy of Citric Acid as a Pulse Treatment}

For both gerbera and alstroemeria, the vase life was not significantly affected $(p>0.05)$ by the concentration of citric acid and duration of pulse treatment (main factors) or the interaction (concentration $\mathrm{x}$ duration) even though some pulse treatments (T2, T3 and T6) improved cut gerbera vase life (Table 1).

Citric acid pulsing was apparently ineffective for gerbera as it caused symptoms of phytotoxicity at the used concentrations and durations, thus resulting in decreased vase life compared to the control (Table 1). A relatively longer vase life was given by 10 and $15 \mathrm{mM}$ citric acid pulses (across the durations). However, the increase was not significant at $95 \%$ confidence level.

Because the treatments which were used in Experiment 1 had no positive effect 
on vase life or apparently not phytotoxic, it was presumed that pulsing with a higher concentration of citric acid would benefit alstroemeria. Therefore, stronger pulse treatments were also tested in Experiment 2. However, those concentrations too did not show any significant effect on cut alstroemeria longevity (Table 1). Although
T7 (25 mM citric acid, $24 \mathrm{~h}$ ) increased the vase life of alstroemeria, it was not significant at $95 \%$ confidence level. In previous research, effect of citric acid has been measured as a vase solution additive (Williamson et al., 2002; Jowkar et al., 2012).

Table 1. Vase life of cut gerbera and alstroemeria flowers when citric acid was used as a pulse treatment (Experiments 1 and 2)

\begin{tabular}{|c|c|c|c|c|}
\hline \multirow{2}{*}{$\begin{array}{c}\text { Experiment } \\
\text { No. }\end{array}$} & \multirow{2}{*}{$\begin{array}{c}\text { Citric acid } \\
\text { concentration } \\
(\mathbf{m M})\end{array}$} & \multirow{2}{*}{$\begin{array}{l}\text { Duration of } \\
\text { pulse } \\
\text { (h) }\end{array}$} & \multicolumn{2}{|c|}{ Vase life (days)* } \\
\hline & & & Gerbera & Alstroemeria \\
\hline \multirow{10}{*}{1} & 0 & - & 4.2 & 5.6 \\
\hline & 5 & 5 & 5.8 & 4.4 \\
\hline & 5 & 16 & 5.6 & 5.8 \\
\hline & 5 & 24 & 4.2 & 5.0 \\
\hline & 10 & 5 & 4.4 & 5.2 \\
\hline & 10 & 16 & 5.4 & 5.2 \\
\hline & 10 & 24 & 4.4 & 5.8 \\
\hline & 15 & 5 & 4.2 & 4.6 \\
\hline & 15 & 16 & 4.8 & 5.6 \\
\hline & 15 & 24 & 3.8 & 5.8 \\
\hline \multirow{10}{*}{2} & 0 & - & - & 4.6 \\
\hline & 15 & 5 & - & 4.8 \\
\hline & 15 & 16 & - & 5.0 \\
\hline & 15 & 24 & - & 5.0 \\
\hline & 25 & 5 & - & 4.6 \\
\hline & 25 & 16 & - & 4.7 \\
\hline & 25 & 24 & - & 5.6 \\
\hline & 30 & 5 & - & 4.7 \\
\hline & 30 & 16 & - & 4.9 \\
\hline & 30 & 24 & - & 5.1 \\
\hline
\end{tabular}

* Treatment effects were not significant $(p>0.05) ; n=5$ 


\section{Efficacy of Citric Acid as a Vase Solution Additive}

The major cause of decrease in vase life of cut flowers is their adverse water relations which could be mostly due to vase solution microbes and various other physical and physiological factors. These obstacles gradually decrease the water uptake rate of cut stems, thereby, shortening their vase life (van Meeteren et al., 2001). In order to reduce vase solution microbial population, most preservatives incorporate acidifying agents, mostly citric acid (Jowkar et al., 2012).

Various citric acid concentrations in Experiment 3 resulted in significant differences $(p=0.0002)$ in vase life of cut gerbera (Table 2). Citric acid at $1 \mathrm{mM}$ concentration gave the highest vase life which is a 2-fold increase when compared to the control (distilled water). Above $1 \mathrm{mM}$ level, however, citric acid tended to decrease the vase life, even though it still maintained vase lives higher than the control at 2 and $5 \mathrm{mM}$ solutions. Higher concentrations of citric acid caused phytotoxicity in gerbera and therefore, 10 $\mathrm{mM}$ citric acid resulted the shortest vase life. Similar toxicities have been observed with citric acid at above optimum concentrations in cut rose flowers (Jowkar et al., 2012). Although application of citric acid increased the vase life of both alstroemeria foliage $(p=0.72)$ and flowers ( $p=0.09)$, the effect was statistically insignificant. The highest flower and foliage vase life of alstroemeria was obtained with $2 \mathrm{mM}$ citric acid vase solution
(Table 2).

Corresponding to the increased longevity, citric acid concentrations of 1 $\mathrm{mM}$ and $2 \mathrm{mM}$ showed the best fresh weight retention during the vase period of gerbera. The lowest relative fresh weight was observed with the highest citric acid concentration $(10 \mathrm{mM})$ which was phytotoxic to gerbera (Figure 1).

Alstroemeria flowers in $2 \mathrm{mM}$ citric acid treatment had the highest fresh weight retention during vase period of cut stems. At most stages, throughout the experiment flowers in the control showed the lowest relative fresh weight (Figure 2).

Both in cut gerbera and alstroemeria, the RFW showed a gradual decline after day 3. However, the decreases in RFW were significantly lower in treatments of citric acid when compared to the control. The high RFW was associated with increased vase life in both species ( $c f$. Table 1 and Figures 1 and 2). The positive effect of citric acid could be attributed to the acidifying and stress alleviating properties of acid, thereby enhancing water uptake and RFW of cut flowers (Vahdati et al., 2012).

Because citric acid vase solution treatment showed a significant positive effect on cut gerbera flowers, Experiment 4 was conducted with addition of sucrose as a source of carbohydrate. Gerbera stems stood in to $1 \%$ and $2 \%$ sugar showed the highest vase life in comparison to other treatments (Experiment 2, Table 2). 
Table 2. Vase life of cut gerbera and alstroemeria with different vase solution citric acid concentrations

\begin{tabular}{clcccc}
\hline $\begin{array}{c}\text { Experi } \\
\text { ment } \\
\text { No. }\end{array}$ & $\begin{array}{c}\text { Citric acid } \\
\text { concentration } \\
(\mathbf{m M})\end{array}$ & $\begin{array}{c}\text { Sugar } \\
\text { concentration } \\
(\%)\end{array}$ & Gerbera & $\begin{array}{c}\text { Alstroemeria } \\
\text { flowers* }\end{array}$ & $\begin{array}{c}\text { Alstroemeria } \\
\text { foliage* }\end{array}$ \\
\hline & 0 (Distilled water) & - & $4.2^{\mathrm{bc}}$ & 6.2 & 5.6 \\
3 & 1 & - & $8.6^{\mathrm{a}}$ & 7.0 & 5.2 \\
& 2 & - & $6.0^{\mathrm{b}}$ & 8.4 & 6.4 \\
& 5 & - & $5.2^{\mathrm{b}}$ & 7.0 & 5.8 \\
& 10 & - & $3.0^{\mathrm{c}}$ & 8.2 & 6.4 \\
\hline & 0 (Control) & 0 & 6.8 & - & - \\
& 0 & 1 & 11.4 & - & - \\
& 0 & 2 & 11.6 & - & - \\
$4 *$ & 0 & 5 & 9.0 & - & - \\
& 1 & 0 & 9.0 & - & - \\
& 1 & 1 & 9.4 & - & - \\
& 1 & 2 & 6.4 & - & - \\
& 1 & 5 & 7.8 & - & - \\
\hline
\end{tabular}

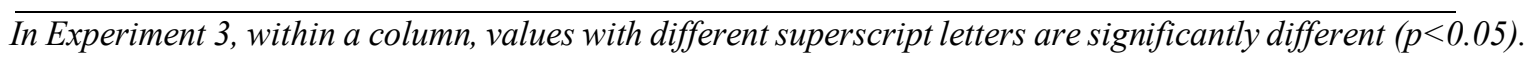
*Treatment effects are not significant $(p>0.05)$

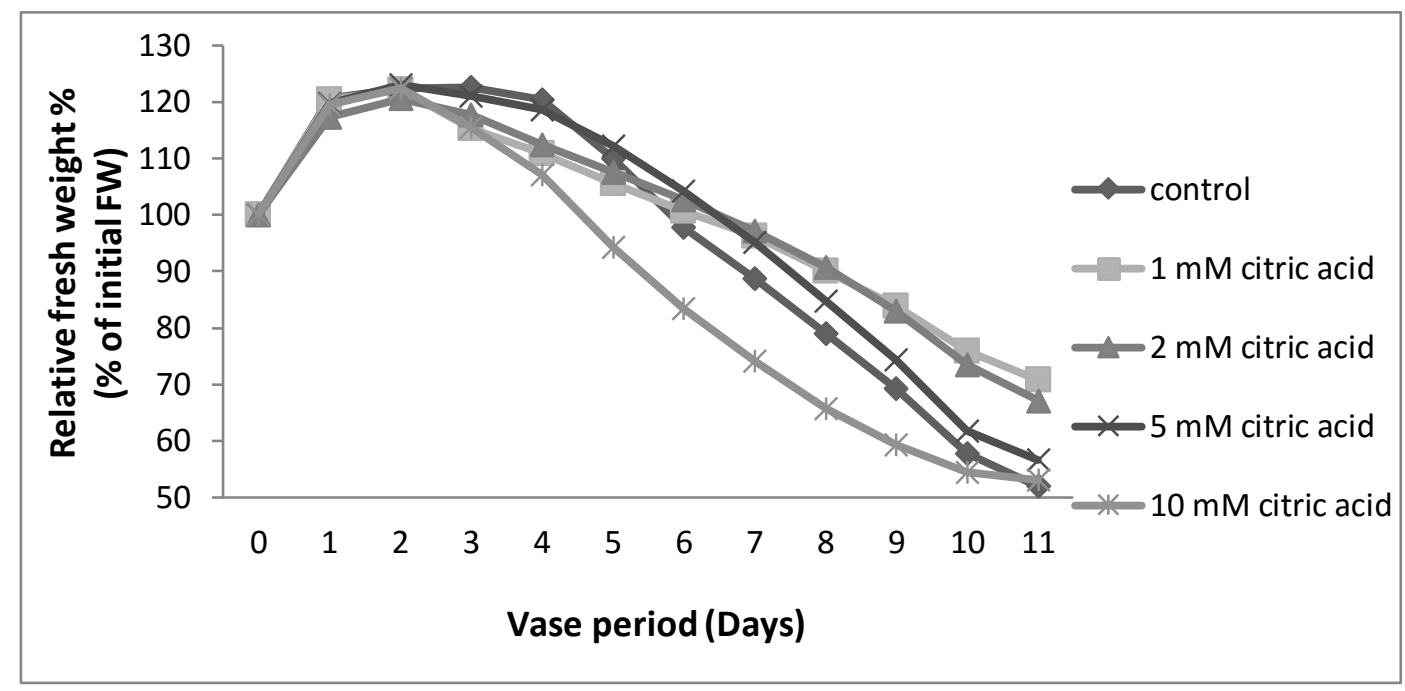

Figure 1. Change of relative fresh weight (RFW) during vase period in cut gerbera with different vase solution citric acid concentrations 


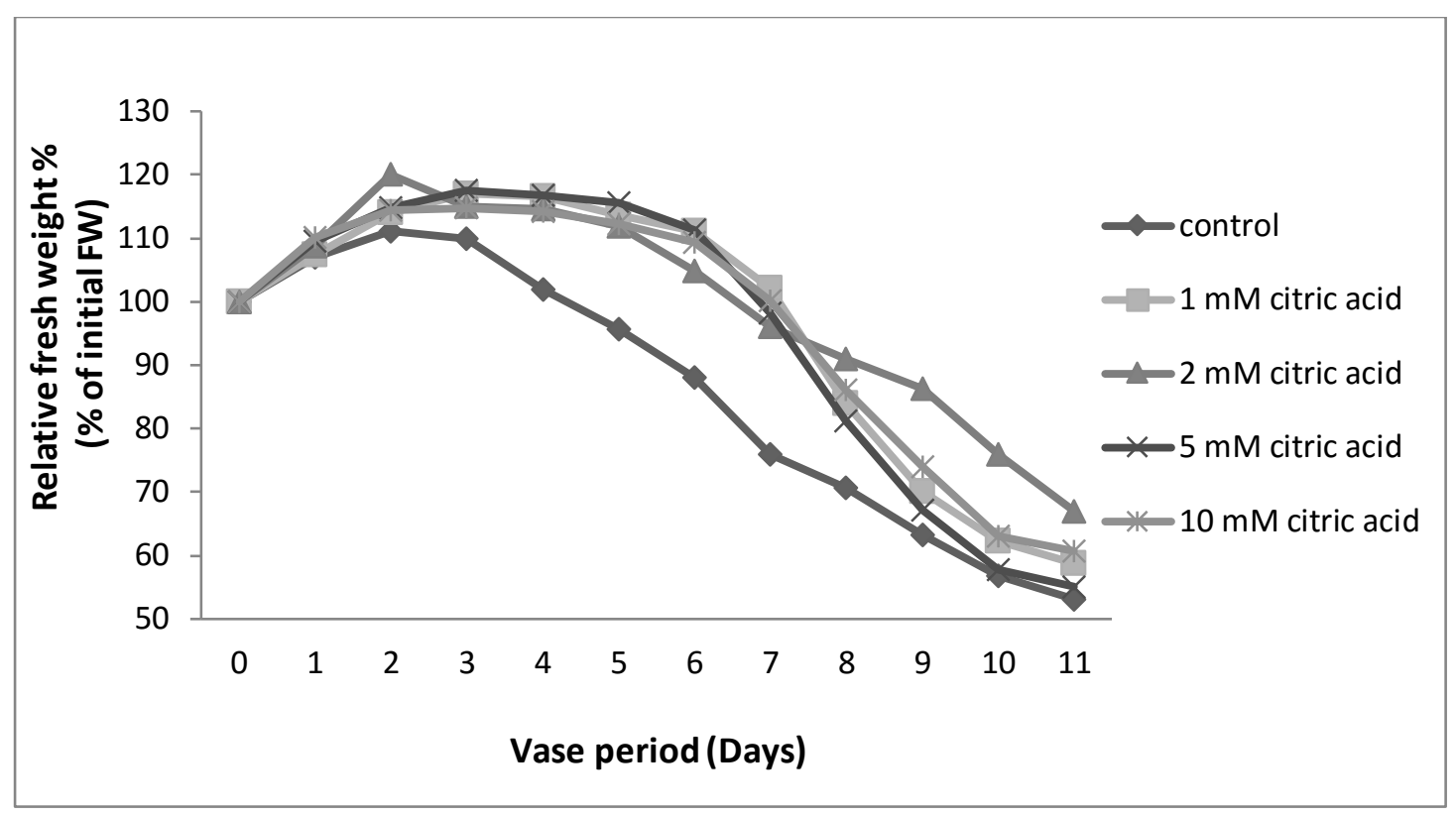

Figure 2. Change of relative fresh weight (RFW) during vase period in cut alstroemeria with different vase solution citric acid concentrations

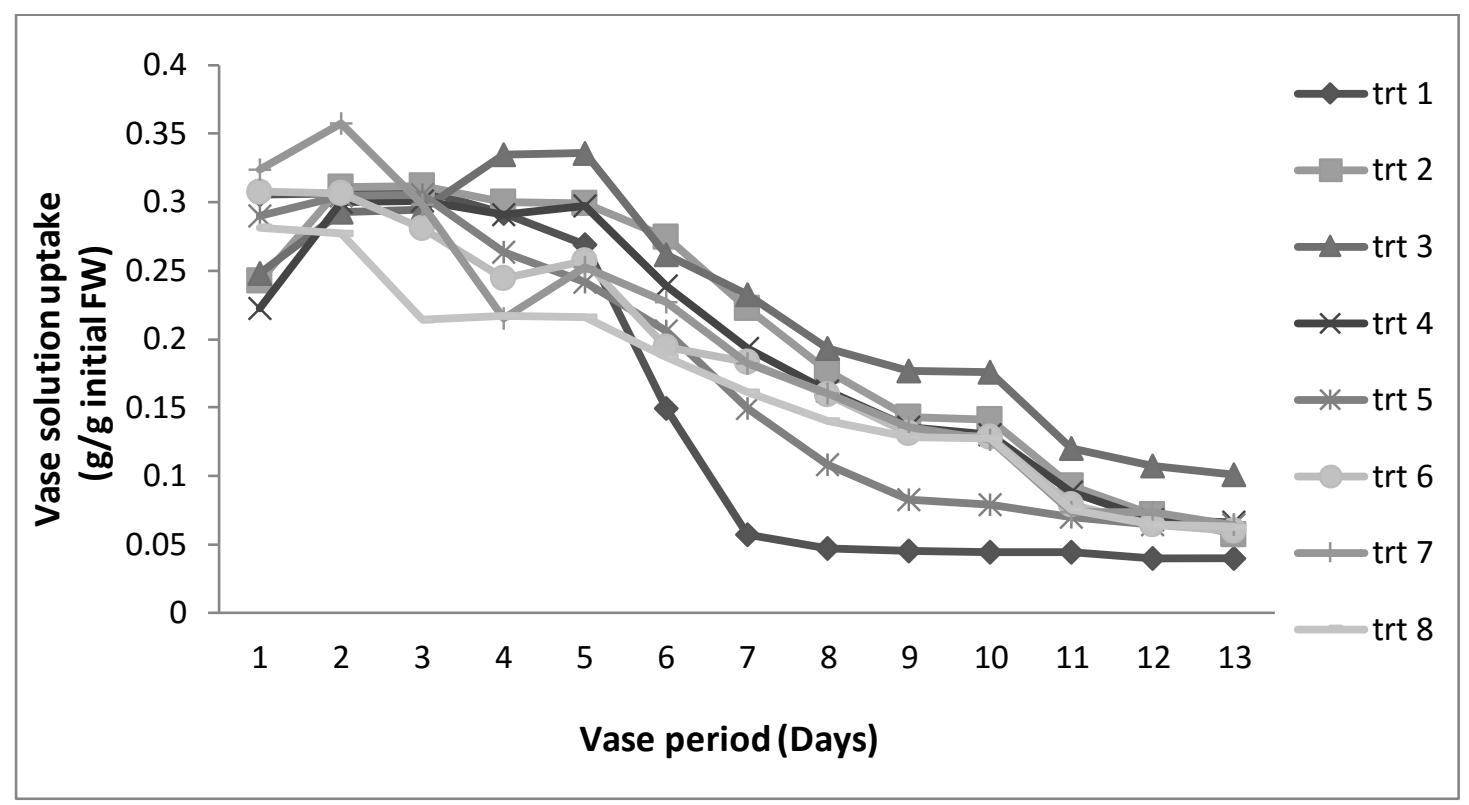

Figure 3. Change of vase solution uptake rate in cut gerbera with various combinations of citric acid and sugar

Treatments (trt): 1) $0 \mathrm{mM}$ Citric acid $+0 \%$ Sugar, 2) $0 \mathrm{mM}$ Citric acid $+1 \%$ Sugar, 3) 0 $m M$ Citric acid $+2 \%$ Sugar, 4) $0 \mathrm{mM}$ Citric acid $+5 \%$ Sugar, 5) $1 \mathrm{mM}$ Citric acid $+0 \%$ Sugar, 6) $1 \mathrm{mM}$ Citric acid $+1 \%$ Sugar, 7) $1 \mathrm{mM}$ Citric acid $+2 \%$ Sugar, 8) $1 \mathrm{mM}$ Citric acid $+5 \%$ Sugar. 
De Silva et al. (2013) also reported an increase in vase life of cut gerbera by adding sugar in the vase solutions. Sugar is widely used as an ingredient in floral preservatives in many countries. It delays the degradation of proteins and improves the water balance of cut flowers (Steinitz, 1982). Although the sugar treatments extended the vase life of gerbera in the present study, the increase was not statistically significant $(p=0.67)$. Combinations of citric acid and sucrose resulted less positive effects on vase life. There was no significant $(p>0.05)$ interaction effect of citric acid and sugar on vase life of cut gerbera.

The highest vase solution uptake rate was shown by $0 \mathrm{mM}$ citric acid + $2 \%$ sugar treatment while the lowest rate was given by the control (Figure 3 ). This result of solution uptake rate however, corresponds to the higher vase life obtained with $1 \%$ and $2 \%$ sucrose levels.

\section{CONCLUSION}

Citric acid pulsing is ineffective for cut gerbera probably due to its high sensitivity. Alstroemeria flowers were tolerant to higher citric acid concentrations. However, the extension of vase life was not significant with pulse treatment. Nevertheless, Citric acid at $1 \mathrm{mM}$ in vase water doubled the vase life of cut gerbera flowers by improving their water relations. A vase solution of $1-2 \%$ sugar was also beneficial. Citric acid vase solution treatments should be further tested with a number of other species and varieties to recognize it as a low cost holding and vase solution for the industry. It is unclear why combinations of citric acid and sucrose resulted less positive effects on vase life. Significant differences among citric acid treatments and the control were not observed for cut alstroemeria possibly due to their high sensitivity to ethylene. The mechanism by which citric acid improved cut stem water relations in gerbera also warrants further research.

\section{ACKNOWLEDGEMENT}

The authors are grateful to Mr. K.H.M.I Karunarathne, Wayamba University of Sri Lanka, for the help given in statistical analysis.

\section{REFERENCES}

Alvarez, V.N., Colinas, L.M.T. and Villanue Va, V.C. (1994). Postharvest uses of chemical compounds to increase vase life of cut tuberose flowers. Horticultural Science, 1: 15-20.

Chandrasena, G.D.R.K., Ratnayake, R.H.M.K. and Edirisinghe, J.C. (2015). Current status of postharvest handling of cut flowers and cut foliage at production sites in the up country of Sri Lanka. In Proceedings of the Young Scientists Forum Symposium 2014. National Science and 
Technology Commission, Sri Lanka, 41- 44.

Delaporte, K.L., Klieber, A. and Sedgley, M. (2000). Postharvest vase life of two flowering Eucalyptus species. Postharvest Biology and Technology, 19: 181186.

De Silva, W.A.N.T., Kirthisinghe, J.P. and Alwis, L.M.H.R. (2013).Extending the vase life of gerbera cut flowers using chemical preservative solutions. Tropical Agricultural Research, 24 (4): 375 $-379$.

Dhanasekara, D.M.U.B. (1998). Cut flower production in Sri Lanka. FAO Publication. Available from: http://www.fao.org/docrep/005/ac 452e/ac452e08.htm. (Accessed 05 March 2014).

Gast, K.L.B. (1997). Commercial specialty cut flower production. Postharvest Handling of Fresh Cut Flowers and Plant Material. Cooperative Extension Service, Kansas State University, MF2261.

He, S., Joyce, D.C., Irving, D.E. and Faragher, J.D. (2006). Stem end blockage in cut Grevillea' Crimson Yul-lo' inflorescences. Postharvest Biology and Technology, 41: 8-84. Idirisinghe, I.M.S.P., Ratnayake, R.H.M.K. and Edirisinghe, J.C. (2013). Current status of postharvest handling of cut flowers and foliage at retail sites of Western and North Western provinces of Sri Lanka. In
Proceeding of the National

Symposium on Floriculture Research (NaSFloR)-2013, Sri Lanka Council for Agricultural Research Policy and Department of National Botanic Gardens, Colombo, Sri Lanka, 27-32.

Jowkar, M.M., Kafi, M., Khalighi, A. and Hasanzadeh, N. (2012). Reconsideration in using citric acid as vase solution preservative for cut rose flowers. Current Research Journal of Biological Science, 4(4): 427-436.

Kelegama, S. (2001). Economics Analysis on Interests and Policy Options for Sri Lanka. In: Agriculture and the New Trade Agenda in the WTO 2000 Negotiations, 34-39.

Khenizy, S.A.M., Zaky, A.A. and Shewaikh, Y.M.E. (2013). Effect of humic acid on vase life of gerbera flowers after cutting. Journal of Horticultural Science \& Ornamental Plants, 5(2): 127-136. Mohammadiju, S., Jafararpoor, M. and Mohammadkhani, A. (2014). Betterment vase life and keeping quality of cut gerbera flowers by postharvest nano silver treatments. International Journal of Farming and Allied Sciences, 4(4): 806-809. Senarathne, R. (2014). Sri Lanka could be a regional leader in floriculture exports. Available from: http://www.ft.lk/2014/03/10/srilanka-could-be-a-regional-leaderinfloriculture-exports- prof-ranjit. (Accessed 10 May 2014). 
Steinitz, B. (1982). Role of sucrose in stabilization of cut gerbera flower stalks. Gartenbouwissenschaft, 47(2): 77-81.

Vahdati, N.M., Tehranifar, A., Bayat, H. and Selahvarzi, Y. (2012). Salicylic and citric acid treatments improve the vase life of cut chrysanthemum flowers. Journal of Agricultural Science and Technology, 14: 879-887.

van Meeteren, U., van Iiperen, W., Nijsse J. and Keijzer, K. (2001). Processes and xylem antimicrobial properties involved in dehydration dynamics of cut flowers. Acta Horticulturae, 543: 207-211.

Williamson, V.G. and Milburn, A.J. (1996). Cavitation events in cut stems kept in water: implications for cut flower senescence. Scientia Horticulturae, 64: 219-232.

Williamson, V. G., Faragher, J., Parsons, S. and Franz, P. (2002). Inhibiting the Postharvest Wounding Responses in Wildflowers. Rural Industries Research and Development Corporation (RIRDC), Barton, ACT, Australia.

Yeat, C.S., Szydlik, M. and Lukaszewska, A.J. (2012). Effect of post-harvest treatments on flower quality and vase life of cut Alstroemeria 'Dancing Queen'. Journal of Fruit and Ornamental Plant Research, 20(2): 147-160. 